\title{
Effect of RU486 on ovarian progesterone production at pro-oestrus and during pregnancy: a possible dual regulation of the biosynthesis of progesterone
}

\author{
C. M. Telleria and R. P. Deis ${ }^{*}$ \\ Laboratorio de Reproducción y Lactancia, CRICYT-CONICET Casilla de correo 855, 5500 Mendoza, \\ Argentina
}

\begin{abstract}
Changes in progesterone production were analysed after intrabursal ovarian administration of the antiprogesterone RU486, mifepristone, in rats at pro-oestrus and during pregnancy. RU486 was administered at 09:00-10:00 h and serum progesterone was measured $8 \mathrm{~h}$ after treatment, except for those on days 3 and 12 of pregnancy when the steroid was measured 4,8 and $24 \mathrm{~h}$ later. RU486 stimulates progesterone production on the day of pro-oestrus and on days 3-5 and 15-20 of pregnancy. Conversely, treatment with the antiprogestagen inhibits progesterone production on days 7-14 of gestation. The inhibition (day 12) or stimulation (day 19) of progesterone production induced by RU486 could be correlated with the simultaneous inhibition or stimulation of $3 \beta$-hydroxysteroid dehydrogenase $(3 \beta-H S D)$ activity observed in corpora lutea. A similar effect on $3 \beta-H S D$ activity in corpora lutea was obtained by intrabursal ovarian administration of a specific progesterone antibody, indicating that the effect of RU486 is exerted through its antiprogesterone action. On the day of pro-oestrus and during early pregnancy the intrabursal ovarian injection of RU486 did not modify serum prolactin and LH concentrations, demonstrating that the antiprogesterone did not have a central action. The stimulatory action of RU486 on progesterone production on days 3 and 5 of pregnancy shifted to an inhibitory effect on progesterone production on day 7. Oestradiol treatment on day 6 of pregnancy reversed the effect of RU486 on progesterone production on day 7 , inducing a response similar to that obtained on days 3 and 5 of gestation. Tamoxifen treatment on days 14 and 15 prevented the stimulatory effect of RU486 on progesterone production observed on day 15 of pregnancy. These results indicated that RU486 is a useful tool to demonstrate a stimulatory and inhibitory direct effect of progesterone on ovarian steroidogenesis, exerted most probably at the corpus luteum, affecting its own biosynthesis. The inhibitory effect of progesterone seems to be oestrogen dependent. The existence of a particular intraovarian regulation of progesterone production in rats during pro-oestrus and pregnancy is suggested.
\end{abstract}

\section{Introduction}

The biosynthesis of ovarian progesterone is under hypophysial and placental control, while gonadal steroids modulate the action of gonadotrophins. The regulation of progesterone synthesis and secretion from the ovary has been studied intensively but there is less information regarding the potential actions of this steroid within the ovary. Fanjul et al. (1983) suggested that intraovarian actions of steroids such as androgens, oestrogens and progestagens may participate in the local control mechanism by regulating follicular development. For instance, progesterone from the corpus luteum may reversibly inhibit the development of small follicles during the luteal phase. With the decrease in progesterone at the time of

*Correspondence.

Received 25 April 1994 luteolysis, further follicular development is resumed (Schreiber et al., 1980). However, progesterone may stimulate follicular recruitment and development, particularly when serum LH is suppressed (Schreiber and Hsueh, 1979; Richards and Bogovich, 1982; Kim and Greenwald, 1987).

Support for a direct action of progesterone on the ovary is indicated by the presence of specific progesterone receptors in the rat ovary (Schreiber and Hsueh, 1979; Naess, 1981; Schreiber et al., 1983) as well as the mRNA encoding progesterone receptors (Park and Mayo, 1991). These two facts taken together suggest a possible direct effect of progesterone on ovarian steroidogenesis. Rothchild (1981) proposed that progesterone might regulate its own secretion, and Park and Mayo (1991) suggested that progesterone exerts an important intraovarian function during the preovulatory LH surge and ovulation. 
Couet ef al. (1990) showed that the last step in progesterone biosyntheis, catalysed by $3 \beta$-hydroxysteroid dehydrogenase $(3 \beta-H S D)$, is controlled at the level of $3 \beta-\mathrm{HSD}$ gene expression or the stability of $3 \beta-\mathrm{HSD}$ mRNA or both factors. Recent studies suggest that the expression of this enzyme is hormonally modulated (Couët et al., 1990; Chedrese et al., 1990; Hawkins ef al., 1993). In particular, rat ovarian 3 $\beta$-HSD activity depends on progesterone concentrations (Tanaka et al., 1993).

RU486 is a synthetic steroid that binds to progesterone receptors acting as a progesterone antagonist (Philibert et al., 1982) without agonist effect (Healy et al., 1983) and is a useful tool for defining the action of progesterone on target organs, both peripherally and centrally (Salicioni et al., 1993; Carón et al., 1994). The aim of this study was specifically to prevent progesterone action within the ovary through the intrabursal ovarian administration of RU486, in an attempt to address the question of whether the ovary itself is a target tissue for a direct effect of the steroid on ovarian steroidogenesis in the presence or absence of oestrogen. A correlation between luteal $3 \beta$-HSD activity and serum progesterone production was also examined. Preliminary results from part of this study have been presented (Tellería and Deis, 1992).

\section{Materials and Methods}

\section{Animals}

Virgin female rats bred in our laboratory (originally Wistar strain) and weighing 180-220 $\mathrm{g}$ at the start of the experiments were used. They were kept under controlled conditions of light (lights on from $06: 00$ to $20: 00 \mathrm{~h}$ ) and temperature $\left(22-24^{\circ} \mathrm{C}\right.$ ); standard rat chow (Nutric, Córdoba) and water were available ad libitum.

Vaginal smears were taken daily, and only rats with 4 day oestrous cycles were used. Rats were caged individually with fertile males on the night of the pro-oestrous day, and the presence of spermatozoa was checked in the vaginal smear the following morning. This day was designated day 0 of pregnancy. In our laboratory, rats usually give birth on day 22 .

All work was in accordance with the NIH Guide for the Care and Use of Laboratory Animals (NIH publication No. 86-23, revised 1985).

\section{Experimental procedures}

The progesterone antagonist RU486 (17ß-hydroxy-11ß-[4dimethyl-aminophenyl]-17 $\alpha$-[1-propynyl]-estra-4,9-diene-3-one; mifepristone: Roussel-Uclaf, Romainville) was administered locally into the ovarian bursa at pro-oestrus and on different days of pregnancy according to the method described by Kannisto et al. (1985). The drug was dissolved in absolute ethanol at a concentration of $1 \mathrm{mmol} \mathrm{I}{ }^{-1}$. Leakage from the bursa was minimized by adding the drug solution in a gel carrier: $0.2 \mathrm{ml}$ of the solution was mixed in $1.8 \mathrm{ml}$ of a $4 \%$ solution of methyl cellulose gel (Sigma Chemical Co., St Louis, $\mathrm{MO}$ ). Both ovaries were exposed through lateral incisions under ether anaesthesia. Each animal received a bilateral intrabursal injection of $25 \mu \mathrm{l}$ of the gel carrier (control group) or gel carrier with RU486 ( $1 \mu \mathrm{g}$ per ovary), between 09:00 and 10:00 h, using a Hamilton microlitre syringe (705-N; Reno,
NV). The rats were decapitated $8 \mathrm{~h}$ after treatment, except for those on days 3 and 12 of pregnancy when different groups were decapitated at 4,8 and $24 \mathrm{~h}$ after RU486 administration.

Two additional groups of animals received a bilateral intrabursal injection of $25 \mu$ l per ovary of an undiluted specific progesterone antiserum raised in our laboratory (Salicioni $e t$ al., 1993). The antiserum was mixed in $4 \%$ solution of methyl cellulose gel and administered at 09:00-10:00 h on days 12 and 19 of pregnancy. The rats were decapitated $8 \mathrm{~h}$ after treatment. Control rats received the same quantity of normal rabbit serum. Blood was allowed to clot at room temperature and the serum separated and stored at $-30^{\circ} \mathrm{C}$ until assayed for hormones. On days 12 and 19 of gestation, both ovaries were removed from each rat, trimmed of surrounding fat, and the corpora lutea were enucleated and stored at $-70^{\circ} \mathrm{C}$ until assayed for enzymes.

Oestradiol benzoate $(5 \mu \mathrm{g}$ per rat; Schering, Buenos Aires) was given s.c. in $0.2 \mathrm{ml}$ of purified sunflower seed oil. Tamoxifen citrate (Gador, Buenos Aires) in $0.14 \mathrm{~mol} \mathrm{NaCl}^{-1}$, $0.5 \%(\mathrm{v} / \mathrm{v})$ Tween 80 was administered per os in two doses of $500 \mu \mathrm{gg}^{-1}$ bodymass.

Determination of $3 \beta-H S D$ and $20 a-H S D$ activities in corpora lutea

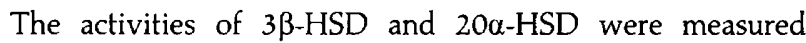
according to Kawano et al. (1988) with a slight modification. Corpora lutea from each animal were homogenized in $0.7 \mathrm{ml}$ $0.1 \mathrm{~mol}$ Tris- $-\mathrm{HCl}^{-1}, 1 \mathrm{mmol} \mathrm{EDTA} \mathrm{I}^{-1}(\mathrm{pH} 8)$ at $0^{\circ} \mathrm{C}$ with a glass homogenizer. The homogenates were centrifuged at $105000 \mathrm{~g}$ for $60 \mathrm{~min}$. The supernatant fluids were used for the assay of $20 \alpha$-HSD activity. The precipitates were rehomogenized with $0.7 \mathrm{ml}$ of $0.2 \mathrm{~mol}$ sucrose $\mathrm{l}^{-1}$ and centrifuged at $800 \mathrm{~g}$ for $5 \mathrm{~min}$. The supernatants were used as the enzyme solution for the assay of $3 \beta-H S D$ activity. Both enzyme activities were assayed spectrophotometrically, dependent on the increase in NADH or NADPH in 1 min at $37^{\circ} \mathrm{C}$ and values were expressed as $\mathrm{mU} \mathrm{mg}^{-1}$ protein. The method of Lowry et al. (1951) was used for the protein determination with BSA as the standard.

\section{Hormone assays}

Serum progesterone was measured using a radioimmunoassay developed in our laboratory (Bussmann and Deis, 1979) with an antiserum raised against progesterone-11-BSA conjugate in rabbits. The sensitivity of the assay was less than $16 \mathrm{nmol} l^{-1}$ serum and the inter- and intra-assay coefficients of variation were less than $10 \%$. Added RU486 had no effect on the progesterone radioimmunoassay.

Prolactin and LH were measured by double-antibody radioimmunoassay using materials provided by the NIADDK (Bethesda, MD). Both hormones were radioiodinated by the chloramine T method (Niswender et al., 1989) and purified by passage through Sephadex G-75 and polyacrylamide agarose (ACA 54; LKB, Bromma) columns.

Results were expressed in terms of the rat prolactin RP-3 and rat LH RP-3 standards. For both hormones, the sensitivity of the assay ranged from 0.5 to $256 \mathrm{ng}$ per sample. Inter- and intra-assay coefficients of variation were less than $10 \%$. 


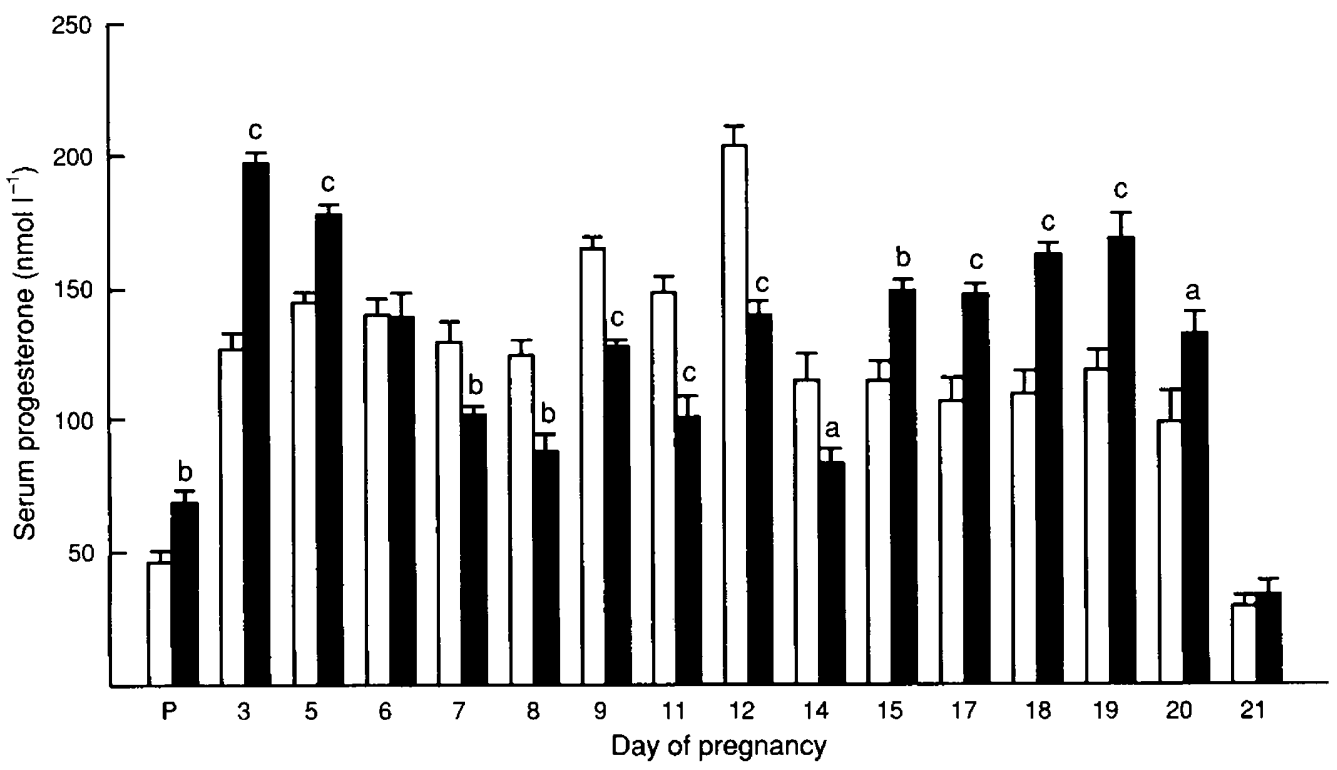

Fig. 1. Serum progesterone concentrations $8 \mathrm{~h}$ after the intrabursal ovarian administration of RU486 ( $\square$ ) or gel carrier $(\square)$ at 09:00-10:00 $\mathrm{h}$ to pro-oestrous rats and rats on different days of pregnancy. $\mathrm{P}=$ Pro-oestrous day. Values are means \pm SEM of groups of six to nine animals; $a, P<0.05, b, P<0.01$, and $c, P<0.001$ compared with its respective control group by Student's $t$ test.

\section{Statistical analyses}

Student's $t$ test was used to assay significant differences between means of two groups. One-way or two-way analysis of variance (ANOVA) followed, respectively, by the Duncan's multiple-range test or the Tau test were used for multiple comparisons. When variances were not homogeneous, logarithmic transformation of data was applied. A $P$ value $<0.05$ was considered statistically significant.

\section{Results}

Serum progesterone concentration on the day of pro-oestrus and on different days of pregnancy after intrabursal ovarian treatment with RU486

Eight hours after RU486 administration, serum progesterone concentration was significantly higher than in controls in pro-oestrous rats and rats at days 3 and 5 of pregnancy (Fig. 1). On day 3 of pregnancy, serum progesterone values 4 and $24 \mathrm{~h}$ after intrabursal treatment with RU486 were not different from control values (control group $4 \mathrm{~h}: 133.7 \pm 11.8 \mathrm{nmol}^{-1}$, $n=6$; RU486 group $4 \mathrm{~h}: 156.9 \pm 7.4 \mathrm{nmol} \mathrm{l}^{-1}, n=6$; control group $24 \mathrm{~h}: 106.1 \pm 15.9 \mathrm{nmol} \mathrm{l}^{-1}, n=6$; RU486 group $24 \mathrm{~h}$ : $\left.137.7 \pm 15.6 \mathrm{nmol}^{-1}, n=6\right)$.

On day 6 of pregnancy, RU486 treatment did not modify serum progesterone concentration. On the contrary, from days 7 to 14 , serum progesterone values $8 \mathrm{~h}$ after RU486 treatment were significantly lower than in their respective controls. On day 12 of pregnancy, serum progesterone values 4 and $24 \mathrm{~h}$ after RU486 treatment were not different from controls (control group $4 \mathrm{~h}: 168 \pm 16.1 \mathrm{nmol} \mathrm{l}^{-1}, n=5$; RU486 group $4 \mathrm{~h}: 135 \pm 5.1 \mathrm{nmol}^{-1}, n=6$; control group
$24 \mathrm{~h}: 226.4 \pm 7.1 \mathrm{nmol}^{-1}, n=5 ; \quad$ RU486 group $24 \mathrm{~h}$ : $232 \pm 12.6 \mathrm{nmol} \mathrm{l}^{-1}, n=6$ )

Towards the end of pregnancy (days 15-20), the circulating concentrations of progesterone were significantly higher in the RU486-treated group than in the control group. These high values were similar to those obtained on days 3 and 5 of pregnancy after treatment with RU486. The physiological decrease in serum progesterone concentration on day 21 of pregnancy was not modified by RU486.

Groups of pregnant rats were treated with a gel carrier containing saline with or without ethanol to ascertain whether the ethanol used to dissolve RU486 affected progesterone synthesis. Serum progesterone concentration after the intrabursal ovarian administration of ethanol $\left(144.1 \pm 7.5 \mathrm{nmol} \mathrm{l}^{-1}\right.$, $n=6$ ) was not different from values obtained after saline administration (148.1 $\left.\pm 6.9 \mathrm{nmol}^{-1}, n=7\right)$.

Serum prolactin and $L H$ concentrations in pro-oestrus and early pregnancy after intrabursal ovarian RU486 treatment

Serum prolactin and LH were measured $8 \mathrm{~h}$ after RU486 treatment in different groups of animals to determine whether the modifications of progesterone production after intrabursal ovarian RU486 administration were due to an extraovarian effect of the antiprogesterone on the secretion of luteotrophic hypophyseal hormones. Serum prolactin concentration on the day of pro-oestrus and on days 3, 5, 8 and 9 of pregnancy, measured $8 \mathrm{~h}$ after RU486 administration, were not different from serum values in control rats receiving an intrabursal gel carrier (Table 1). Serum LH concentration in rats at pro-oestrus after RU486 treatment $\left(11.3 \pm 2.4 \mu \mathrm{g} \mathrm{l}^{-1}, n=7\right)$ was not different from that of control vehicle-treated rats $(10.5 \pm 2.4 \mu \mathrm{g}$ $\left.1^{-1}, n=6\right)$. Serum LH concentrations were not detectable in early pregnancy in controls and RU486-treated rats. 
Table 1. Serum prolactin concentrations on the day of prooestrus and during early pregnancy in rats treated intrabursally with RU486

\begin{tabular}{lrr}
\hline & \multicolumn{2}{c}{ Control } \\
& \multicolumn{1}{c}{ RUactin $\left(\mu \mathrm{g} \mathrm{l}^{-1}\right)$} \\
\hline Pro-oestrus & $143.3 \pm 13.4(6)$ & $122.5 \pm 15.0(6)$ \\
Day 3 & $50.1 \pm 11.5(6)$ & $33.2 \pm 13.4(6)$ \\
Day 5 & $14.3 \pm 3.0(6)$ & $16.2 \pm 2.7(7)$ \\
Day 8 & $8.7 \pm 2.1(6)$ & $5.7 \pm 1.0(7)$ \\
Day 9 & $2.9 \pm 0.4(6)$ & $2.5 \pm 0.2(6)$ \\
\hline
\end{tabular}

Rats were treated with either RU486 or gel carrier at 09:00-10:00 h on pro-oestrous day and on days 3, 5, 8 and 9 of pregnancy. Serum prolactin was measured $8 \mathrm{~h}$ after treatment. Values are means \pm SEM for the number of animals in parentheses.

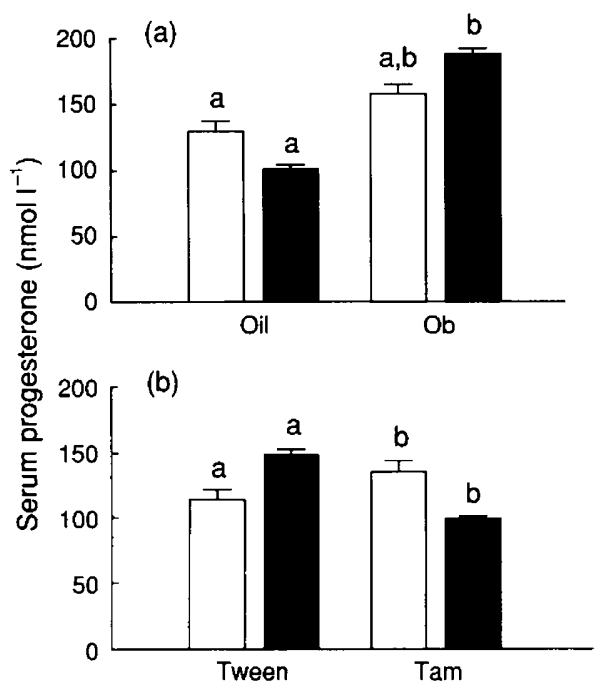

Fig. 2. (a) Serum progesterone concentrations $8 \mathrm{~h}$ after intrabursal ovarian administration of RU486 ( $\square$ ) or gel carrier $(\square)$ at 09:00$10: 00 \mathrm{~h}$ in rats on day 7 of pregnancy treated with vehicle (oil) or oestradiol benzoate $(\mathrm{Ob} ; 5 \mu \mathrm{g}$ per rat subcutaneously on day 6 of pregnancy at 18:00 h). (b) Serum progesterone concentrations $8 \mathrm{~h}$ after the intrabursal ovarian administration of RU486 ( $\square$ ) or gel carrier $(\square)$ at 09:00-10:00 h to rats on day 15 of pregnancy treated with vehicle (Tween; Tween 80) or tamoxifen citrate (Tam; tamoxifen citrate in two doses of $500 \mu \mathrm{g} \mathrm{kg}^{-1}$ per os at 12:00 h on days 14-15 of pregnancy). Results are means \pm SEM of groups of six to nine animals. Columns with the same letter differ significantly ( $a, b$ : $P<0.01$; two-way ANOVA followed by the Tau test).

Serum progesterone concentration after pretreatment with oestrogen, tamoxifen and intrabursal ovarian administration of RU486

The participation of oestrogen in the RU486-induced modification of progesterone production was examined by treating two groups of rats with oestradiol benzoate (Fig. 2a) or tamoxifen citrate (Fig. 2b). After oestrogen treatment, serum progesterone concentration was significantly higher $8 \mathrm{~h}$ after the intrabursal injection of RU486 on day 7 of pregnancy. Thus, oestrogen treatment reversed the depressed ovarian

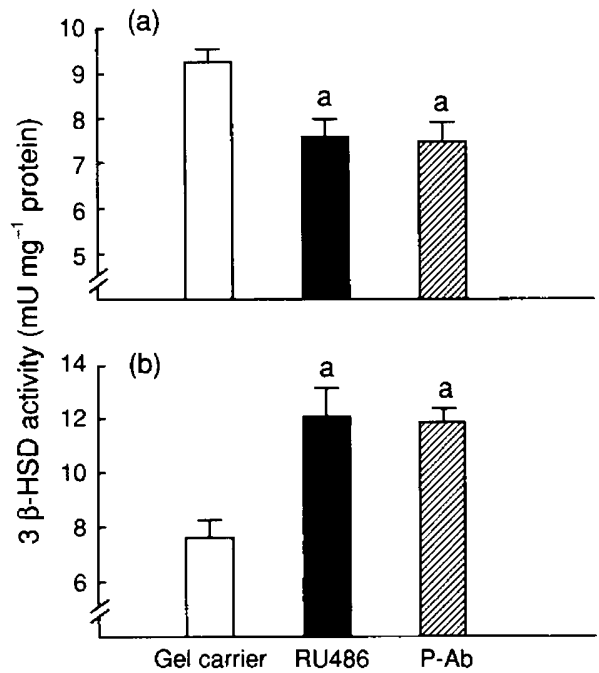

Fig. 3. Luteal $3 \beta$-hydroxysteroid dehydrogenase ( $3 \beta$-HSD) activity $8 \mathrm{~h}$ after the intrabursal ovarian administration of RU486 ( $\square$ ), gel carrier $(\square)$ or progesterone antiserum $(\square)$ at 09:00-10:00 $\mathrm{h}$ to rats on (a) day 12 or (b) day 19 of pregnancy. Results are means \pm SEM from six to nine animals; $a, P<0.01$ compared with gel carrier (one-way ANOVA followed by Duncan's multiple range test). No difference was observed between groups receiving gel carrier with or without normal rabbit serum; therefore all results for control rats have been pooled.

progesterone production induced by RU486 in rats pretreated with the vehicle. Oestrogen alone induced a significant increase in serum progesterone, but it was significantly lower than that obtained by combined treatment with oestrogen and RU486.

After tamoxifen and RU486 treatment at day 15 of pregnancy, serum progesterone concentration was significantly lower than in tamoxifen and vehicle-treated rats. This low serum progesterone value was significantly different from the high value in serum progesterone induced by the intrabursal ovarian administration of RU486 to rats pretreated with the vehicle.

Activities of luteal enzymes on days 12 and 19 of pregnancy after intrabursal ovarian administration of $R U 486$ or progesterone antiserum

$3 \beta$-HSD activity was significantly lower in both RU486 and progesterone antiserum-treated rats on day 12 of pregnancy when compared with the control group (Fig. 3a). Conversely, after RU486 or progesterone antiserum administration, $3 \beta-H S D$ activity was significantly higher than that observed in the control group on day 19 of pregnancy (Fig. 3b). The decrease or increase of $3 \beta-\mathrm{HSD}$ activity induced by RU486 treatment showed a good correlation with the simultaneous modifications in serum progesterone concentration (see Fig. 1). In neither experimental groups was $20 \alpha-$ HSD activity detectable (results not shown).

\section{Discussion}

Ovarian progesterone biosynthesis is primarily controlled by pituitary and placental hormones; however, the possibility of 
autocrine and paracrine controls of progesterone production in the ovary has been postulated. Rothchild (1965, 1981) examined the evidence of the autonomy of the corpus luteum on progesterone secretion in hypophysectomized animals, and suggested that progesterone may modulate its own production at the corpus luteum.

Stimulatory and inhibitory effects of RU486 on progesterone biosynthesis have been reported. Thus the spontaneous induction in isolated rat corpora lutea of $20 \alpha-\mathrm{HSD}$, an enzyme that converts progesterone into a derivative devoid of progestational activity (Wiest $e$ al., 1968), is inhibited by the addition of the progesterone antagonist RU486 to the culture medium (Uilenbroek et al., 1992a), inducing an increase in progesterone accumulation. However, a direct effect on progesterone biosynthesis in human granulosa cells, with a significant correlation between increasing doses of RU486 and decreasing progesterone production, was demonstrated by Dimattina ef al. (1986, 1987). The results obtained at pro-oestrus and on days 3 and 5 , and from days 15 to 20 of pregnancy, suggest intraovarian regulation of progesterone production through negative feedback of the steroid on its own production at the ovary during these reproductive states. These effects of RU486 correlate with the capacity of the synthetic progestin R5020 to inhibit gonadotrophin-stimulated progesterone production in rat granulosa cells (Schreiber et al., 1980). In contrast to that observed on the other days of pregnancy, the low serum progesterone concentrations obtained when RU486 was administered from day 7 to day 14 may indicate a positive self regulation of progesterone production at this time of pregnancy. These results are in agreement with those obtained by Fanjul et al. (1983), who demonstrated that R5020 enhances gonadotrophin-stimulated progesterone production in rat granulosa cells, exerting a direct stimulatory action on progesterone biosynthesis.

Uilenbroek et al. (1992b) observed that RU486 has a negative effect on steroidogenic rat ovarian enzymes and suggested that this is mainly due to lower $3 \beta-H S D$ activity. In accordance with this, Tanaka et al. (1993) showed a decrease in ovarian 3 $\beta$-HSD activity after RU486 treatment in gonadotrophin-primed immature rats. Our results also indicate that RU486 regulates the activity of ovarian $3 \beta-\mathrm{HSD}$. The decrease (day 12) and increase (day 19) in luteal $3 \beta-H S D$ activity correlate with the respective changes in serum progesterone concentrations in rats receiving RU486 into the ovarian bursa. In these rats $20 \alpha-\mathrm{HSD}$, known to have a pivotal role in the mechanism of luteolysis (Wiest and Forbes, 1964; Bast and Melampy, 1972), was not activated by RU486, indicating that $8 \mathrm{~h}$ after intrabursal treatment with the antiprogestagen, the corpora lutea are still active. The mechanism by which RU486 modified $3 \beta-H S D$ activity is unknown. We cannot discount the possibility that RU486 acts through a direct interaction with $3 \beta$-HSD. However, it seems likely that RU486 inhibits $3 \beta-H S D$ activity, acting as a progesterone receptor antagonist. This contention is supported by the binding of RU486 to progesterone receptors in the cytoplasm of rat granulosa cells (Schreiber and Hsueh, 1979; Schreiber et al., 1983). Since progesterone receptors have not been found in rat luteal cells, the antiprogestin may act on some other cell type within the ovary, resulting in the production of a factor that modifies luteal progesterone production.
RU486 has a high binding affinity for progesterone and glucocorticoid receptors (Philibert et al., 1982; Moguilewsky et al., 1982). Both receptors are present in the rat ovary (Schreiber and Hsueh, 1979; Schreiber et al., 1982). However, the results obtained with the intrabursal ovarian administration of the specific progesterone antibody showing significant changes in $3 \beta$-HSD activity on days 12 and 19 of pregnancy are a good indication that the effect of RU486 on progesterone production is through its antiprogesterone action rather than its capacity to block glucocorticoid receptors.

It is known that prolactin secreted by the pituitary is essential to maintain basal progesterone production in rats during the first week of pregnancy (Gibori and Keyes, 1980). Therefore, a possible central action of RU486 administered into the ovarian bursa was taken into account. We have demonstrated that systemic administration of 1 or $2 \mathrm{mg}$ of RU486 $\mathrm{kg}^{-1}$, doses higher than those administered intrabursally, is not centrally effective in inducing prolactin release in pregnant rats (Deis et al., 1989; Jahn and Deis, 1991; Jahn et al., 1993). We now show that serum LH and prolactin concentrations in rats at pro-oestrus and on days 3, 5, 8 and 9 of pregnancy are not different from control values. Thus, the increase in serum progesterone noted after the intrabursal ovarian administration of RU486 at pro-oestrus and on different days of pregnancy cannot be attributed to an increase in circulating $\mathrm{LH}$ or prolactin. In the present study we did not consider a possible effect of RU486 on the secretion of such placental hormones as placental lactogen or androgens that regulate luteal function during the second half of pregnancy (Gibori et al,, 1988). Progesterone directly decreases placental lactogen II production in vitro (Soares and Glacer, 1987), but it is uncertain whether progesterone is a physiological regulator of placental lactogen production (Soares et al., 1991). Moreover, the small amount of RU486 administered ( $1 \mu \mathrm{g}$ per ovary), as well as the high density of the vehicle used, may exclude a placental effect of the antiprogestin that would otherwise mask a direct ovarian action.

Before egg implantation, there is an increase in serum oestrogen concentrations on day 3 of pregnancy, after which the steroid concentration remains very low until day 15-16 when it starts to increase progressively until parturition (Yoshinaga et al., 1969; Shaikh, 1971). The shift of the effect of intrabursal ovarian treatment with RU486 on progesterone production obtained on days 6-7 and 14-15 of pregnancy, seems coincident with either the decrease or increase of oestrogen concentrations in the circulation. The administration of oestradiol on day 6 of pregnancy prevented the shift of the antiprogesterone effect which took place on days 6 and 7 of pregnancy and serum progesterone concentration on day 7 after RU486 treatment was similar to that obtained on days 3 and 5 of gestation. Furthermore, treatment with the oestrogen antagonist, tamoxifen, on days 14 and 15 of pregnancy, prevented the stimulatory effect of RU486 on progesterone production observed on day 15.

The intrabursal ovarian administration of the antiprogesterone RU486 allowed us to postulate the existence of a dual intraovarian regulation by progesterone on its own production. Moreover, the inhibitory action of progesterone on its own biosynthesis seems to be mediated by oestrogen. 
This work was supported by grant PLI-014/90 from PLACIRH (Programa Latinoamericano de Capacitación e Investigación en Reproducción Humana) and in part by grant No. 3-122100/88 from CONICET (Consejo Nacional de Investigaciones Científicas y Técnicas, Argentina). C. M. Telleria is a fellow and R. P. Deis is a career scientist from the CONICET. The authors thank the Hormone Distribution Program, NIADDK, for kindly providing the materials for the prolactin and LH radioimmunoassays, Roussel-Uclaf (Romainville, France) for providing RU-38486, Schering (Buenos Aires) for the gift of oestradiol benzoate and Laboratorio Gador (Buenos Aires) for the gift of tamoxifen citrate. The authors gratefully acknowledge the helpful criticism of Professor Catherine Wilson in reviewing the manuscript.

\section{References}

Bast JD and Melampy RM (1972) Luteinizing hormone, prolactin and ovarian 20a-hydroxysteroid dehydrogenase levels during pregnancy and pseudopregnancy in the rat Endocrinology 91 1499-1505

Bussmann LE and Deis RP (1979) Studies concerning the hormonal induction of lactogenesis by prostaglandin F2 $\alpha$ in pregnant rats Joumal of Steroid Biochemistry 11 1485-1489

Caron RW, Salicioni AM and Deis RP (1994) Mifepristone treatment demonstrates the participation of adrenal glucocorticoids in the regulation of oestrogen-induced prolactin secretion in ovariectomized rats Journal of Steroid Biochemistry and Molecular Biology 48 385-389

Chedrese PJ, The VL, Labrie F, Juoric AV and Murphy BD (1990) Evidence for the regulation of $3 \beta$-hydroxysteroid dehydrogenase messenger RNA by human chorionic gonadotropin in luteinized porcine granulosa cells Endocrinology $126 \quad 2228-2230$

Couët J, Martel C, Dupont E, The VL, Sirard M-A, Zhao H-F, Pelletier G and Labrie $F$ (1990) Changes in 3 $\beta$-hydroxysteroid dehydrogenase $/ \Lambda^{5}-\Lambda^{4}$ isomerase messenger ribonucleic acid, activity and protein levels during the estrous cycle in the bovine ovary Endocrinology 127 2141-2148

Deis RP, Carrizo DG and Jahn GA (1989) Suckling-induced prolactin release potentiates mifepristone-induced lactogenesis in pregnant rats Journal of Reproduction and Fertility 87 147-153

Dimattina M, Albertson B, Seyler DE, Loriaux DL and Falk RJ (1986) Effect of the antiprogestin RU486 on progesterone production by cultured human granulosa cells: inhibition of the ovarian $3 \beta$-hydroxysteroid dehydrogenase Contraception 34 199-206

Dimattina M, Albertson B, Tyson V, Loriaux DL and Falk RJ (1987) Effect of the antiprogestin RU486 on human ovarian steroidogenesis Ferfility and Sterility $48229-233$

Fanjul LF, Ruiz de Galarreta CM and Hsueh AJW (1983) Progestin augmentation of gonadotropin-stimulated progesterone production by cultured rat granulosa cells Endocrinology 112 405-407

Gibori G and Keyes PL. (1980) The role of estradiol in early pregnancy in the rat Endocrinology 106 1584-1589

Gibori G, Khan I, Warshaw ML, McLean MP, Puryear TK, Nelson S, Durkee TJ, Azhar S, Steinschneider A and Rao MC (1988) Placental derived regulators and the complex control of luteal cell function. Recent Progress in Hormone Research 44 377-429

Hawkins DE, Belfiore CJ, Kile JP and Niswender GD (1993) Regulation of messenger ribonucleic acid encoding $3 \beta$-hydroxysteroid dehydrogenase/ $\Delta^{5}-\Delta^{4}$ isomerase in the ovine corpus luteum Biology of Reproduction 48 $1185-1190$

Healy DL, Baulieu EE and Hodgen GD (1983) Induction of menstruation by antiprogesterone steroid (RU486) in primates: site of action, dose-response relationships and hormonal effects Fertility and Sterility 40 253-257

Jahn GA and Deis RP (1991) Involvement of the adrenergic system in the release of prolactin and lactogenesis at the end of pregnancy in the rat Journal of Endocrinology 129 343-350

Jahn GA, Rastrilla AM and Deis RP (1993) Correlation of growth hormone secretion during pregnancy with circulating prolactin in rats journal of Reproduction and Fertility 98 327-333

Kannisto P, Owman Ch and Walles B (1985) Involvement of local adrenergic receptors in the process of ovulation in gonadotrophin-primed immature rats Journal of Reproduction and Fertility 75 357-362

Kawano T, Okamura H, Tajima C, Fukuma K and Katabuchi H (1988) Effect of RU486 on luteal function in the early pregnant rat Journal of Reproduction and Fertility 83 279-285
Kim I and Greenwald GS (1987) Stimulatory and inhibitory effects of progesterone on follicular development in the hypophysectomized folliclestimulating hormone/luteinizing hormone-treated hamster Biology of Reproduction 36 270-276

Lowry OH, Rosebrough NJ, Farr AL and Randall RJ (1951) Protein measurement with the folin phenol reagent journal of Biological Chemistry 193 265-276

Moguilewsky M, Deraedt R, Teutsch G and Philibert D (1982) RU-38486. An antiglucocorticoid with a new mechanism of antihormonal activity Journal of Steroid Biochemistry 17, Ixviii, Abstract 203

Naess O (1981) Characterization of cytoplasmic progesterone receptors in rat granulosa cells. Evidence for nuclear translocation Acta Endocrinologica 98 288-294

Niswender GD, Chen CL, Midgley AR Jr, Meites J and Ellis S (1989) Radioimmunoassay for rat prolactin Proceedings of the Society for Experimental Biology and Medicine $130793-797$

Park Ok-K and Mayo KE (1991) Transient expression of progesterone receptor messenger RNA in ovarian granulosa cells after the preovulatory luteinizing hormone surge Molecular Endocrinology 5 967-978

Philibert D, Deraedt R, Tournemine C, Mary I and Teutch G (1982) RU-38486. A potent antiprogesterone Joumal of Steroid Biochemistry 17, lxviii, Abstract 204

Richards JS and Bogovich K (1982) Effects of human chorionic gonadotropin and progesterone on follicular development in the immature rat Endocrinology 111 1429-1438

Rothchild I (1965) Interrelations between progesterone and the ovary, pituitary and central nervous system in the control of ovulation and the regulation of the progesterone secretion Vitamins and Hormones 23 209-327

Rothchild I (1981) The regulation of the mammalian corpus luteum Recent Progress in Hormone Research 37 183-298

Salicioni AM, Carón RW and Deis RP (1993) Adrenal progesterone facilitates the negative feedback of oestrogen on LH release in ovariectomized rats Journal of Endocrinology 139 253-258

Schreiber JR and Hsueh AJW (1979) Progesterone receptor in rat ovary Endocrinology 105 915-919

Schreiber JR, Nakamura K and Erickson GF (1980) Progestins inhibit FSHstimulated steroidogenesis in cultured rat granulosa cells Molecular and Cellular Endocrinology 19 165-173

Schreiber JR, Nakamura K and Erickson GF (1982) Rat ovary glucocorticoid receptor: identification and characterization Steroids 35 569-584

Schreiber JR, Hsueh AJW and Baulieu EE (1983) Binding of antiprogestin RU486 to rat ovary steroid receptors Contraception 28 77-85

Shaikh AA (1971) Estrone and estradiol levels in the ovarian venous blood from rats during the estrous cycle and pregnancy Biology of Reproduction 5 297-307

Soares MJ and Glacer SR (1987) Placental lactogen production and functional differentiation of rat trophoblast cells in vitro Journal of Reproduction and Fertility 79 335-341

Soares MJ, Faria TN, Roby KF and Deb S (1991) Pregnancy and the prolactin family of hormones: coordination of anterior pituitary, uterine, and placental expression Endocrine Reviews 12 402-423

Tanaka N, Iwamasa J, Matsuura K and Okamura H (1993) Effects of progesterone and anti-progesterone RU486 on ovarian $3 \beta$-hydroxysteroid dehydrogenase activity during ovulation in the gonadotrophin-primed immature rat Journal of Reproduction and Fertility 97 167-172

Tellería CM and Deis RP (1992) Efecto del RU486 (Mifepristona) sobre la secreción de progesterona en el cuerpo lúteo de rata. Proceeding of the I Iberoamerican Congress of Pharmacology, Spain. In Revista Española de Farmacología Clinica y Experimental (special number) Abstract 288

Uilenbroek JThJ, Woutersen PJA and Karels B (1992a) Inhibition of induction of $20 \alpha$-hydroxysteroid dehydrogenase activity in rat corpora lutea in vitro by the progesterone antagonist RU486 Life Sciences 50 1173-1178

Uilenbroek JThJ, Sánchez-Criado JE and Karels B (1992b) Decreased luteinizing hormone-stimulated progesterone secretion by preovulatory follicles isolated from cyclic rats treated with the progesterone antagonist RU486 Biology of Reproduction 47 368-373

Wiest WG and Forbes TR (1964) Failure of 20a-hydroxy- $\Delta^{4}$-pregnen-3-one and $20 \beta$-hydroxy- $\Delta^{4}$-pregnen-3-one to maintain pregnancy in ovariectomized mice Endocrinology 74 149-150

Wiest WG, Kidwell WR and Bologh K Jr (1968) Progesterone catabolism in the rat ovary: a regulatory mechanism for progestational potency during pregnancy Endocrinology 82 844-852

Yoshinaga K, Hawkins RA and Stocker JF (1969) Estrogen secretion by the rat ovary in vivo during estrous cycle and pregnancy Endocrinology 85 103-112 